\title{
投稿規 定
}

1. 綜説は長さと制限を設けないが原稿用紙（400字詰） 50枚以内を希望する。

2. 原著は順天堂医学会会員の研究作限り, 刷上り 4 頁 以内とし，それ以上は実費を徵集する。余り長いも のは揭載困難なことがある。

3. 症例, 実験などの報告及び速報は刷上り 2 頁以内と し，それ以上は実費を徴収する。

4. 印刷代及び插図, 写真などの版代は, 著者負担とす る。但し綜説，原著及び報告などの別刷は，30部ま で無料とする。

5. 投稿原稿，依頼原稿を問わず，原稿にはすべて英文 の標題，著者名を付け，原著論文はさらに 400 語以 内の英文 Summary と 600 字以内の和文抄録（前 文）をつける。

6. 原稿の取捨選択, 揭載順序などは編集委員会が決定 する。

7. 原稿の送り先は下記の通り。

于113 東京都文京区本郷 2 丁目 1 番 1 号 順天堂大学内 順天堂医学編集室 （振替口座東京 6-65006 番）

8. 原稿の書き方は, 次の要領による。

a. 原稿証表紙を附し, 上半分飞は表題, 著者名 下半分には所属名, 表及び插図の数, 別刷請求 部数, 編集者への注意事項（例えば原著, 報告 の別）などを記す。

b. 原稿は, 当用漢字新仮名づかい平仮名まじり横
書とし，簡潔机楷書で書く。

c . 外国語は原語の場合は活字体(なるべくタイプ) 邦文の場合は片仮名を用いる。

d. 数字は算用数字を用い, 単位は原則としてCGS 単位による。単位符号の後には点をつけない （g. でなく g )。特殊の単位を用いる場合は必 ず簡単な説明を加光る。

e . 插図及び表は本文とは別汇し図1, 表1などの 番号呿よび表題, 説明をつける。本文中の挿入 すべき場所の欄外飞別飞朱字でその位置を指定 する。

f . 文献は引用順とし, 末尾文献リストの番号を片 括弧江入れて右上肩飞つける。（例, 橋本ら によれば …………)。

文献引用例

日本文の例

1）橋本博史：エリテマトーデスと免疫：順天堂医 学, 22, 253〜264, 1976.

英文の例

2) Bridge, R. G. \& F. E. Foley : Placental transmission of the lupus erythematosus factor.: Am. J. Med. Sci., 227, 1 5, 1954.

9. 教室主任名, 研究指導者名は論文の第 1 頁飞は揭載 しない。

「順天堂医学」は広く，医学会の新知識を紹介することを基本方針とし，毎号特集形式で編集す る。その原稿は編集委員会から執筆者に依頼する。このほかに原著論文なども揭載するが，掲載希 望者は上記の投稿規定を守って戴きたい。依頼原稿に対しては別に規定された原稿料を呈する。投 稿原稿については，規定の掲載料を徵集する。

特集主題について会員各位のご意見，ご希望を編集室宛およせ下さい。 